Pepys of this commission, as the season was favourable. On March 22, the subject of Holmes's watches arose, and Pepys was requested to procure the journals of those masters of ships who had been with Holmes in Guinea and differed from him.

The incidence of the Plague and the Great Fire which followed were periods of intensive public anxiety and apprehension, and we lose contact with the College world for some time. But on November 14, 1666, Pepys records that Dr. Croone had told him that at that night's meeting, "which, it seems, they now have every Wednesday again", there were experiments on blood transfusion. A year later (November 21, 1667), there is another reference:-

. . "I to the office, where did much business till after candlelight, and then my eyes beginning to fail me, I out and took coach to Arundell House, where the meeting of Gresham College was broke up ; but there meeting Creed, I with him to the taverne in St. Clement's Churchyard."

On November 30, 1667, Pepys tells us that he went to Arundel House to the election of officers of the Royal Society for the next year; that he was near being chosen, but glad that he was not, for he could not have attended, but took it as a mighty respect to have been named. Also, that the company was great, the elections long.

On April 2, 1668, Pepys mentions a visit to the Royal Society, with Lord Brouncker, and of being "forced to subscribe" to the building of a College; and that he "did give forty pounds". Pepys held views adverse to the scheme, and these may have reflected themselves in a partial withdrawal of interest, for not until November 30, 1674, do we again pick up the threads of association with the Society. But it is with enhanced prestige. At the anniversary meeting, Mr. Pepys is among ten new members chosen for the council. His ally, Sir Joseph Williamson (P.R.S., 1677), was also of the number. Pepys attended the meeting on December 3, when a resolution was taken that every member of council should provide an experimental discourse for the Society, to be made within the year, either by himself or by some other member of the Society; or, "to pay forty shillings". Pepys promised a discourse.

On December 17, Pepys is placed upon a committee to consider how Dr. Wilkins's legacy of $\mathfrak{1 4 0 0}$ might be laid out. Also, he was joined with Sir R. Southwell and the president in an application to Prince Rupert "concerning the mischief which his glass-house does to Chelsea College". In January ensuing the president announced his discourse. Mr. Pepys, he said, had offered to make his the next week after his own; it does not appear, however, that Pepys held to his offer.

On February 18, 1674-5, "Mr. Isaac Newton" was admitted a fellow. Since Pepys was a member of council, there is a presumption that he was present on this particular occasion. Pepys was irregular in his attendances, however, during the year, and he was not continued on the council. But his light was only temporarily dimmed, for on November 30,1676 , he re-appears as one of ten new members, and among these were Sir Christopher Wren and John Evelyn. Again Pepys served twelve months.

In the politically stormy year of 1680, "far away at Newmarket, Pepys was taking down, at the dictation of his sovereign, the tale of that miraculous escape from Worcester of twenty-nine autumns before" (Bryant).

We now pass to the year 1681, when Pepys re-appears in the Royal Society. At the anniversary meeting on November 30 , he enters the council, and with him, Evelyn and Flamsteed; Sir Christopher Wren is president. Hooke was a colleague. Pepys served for one year. Coming to 1684 , at the anniversary meeting on December 1 (St. Andrew's Day falling on a Sunday), Sir John Hoskyns in the chair, Samuel Pepys, chosen for the council, is also elected president of the Society. Notwithstanding that his attendances were infrequent, he was, in 1685, continued in the presidency for yet another year, this nomination marking the closing and final period in that office.

Here it may be mentioned that at a council on June 2, 1686, the first book of Newton's "Principia" was ordered to be printed. Pepys was not present, nor on June 30 , when it was ordered that the president be desired to license the book. Sir John Hoskyns occupied the chair. Pepys's imprimatur was given on July 5 .

Samuel Pepys was never a very healthy man, and he died at Clapham on May 26, 1703. He was buried in St. Olave's Church, Crutched Friars. His portrait, by Kneller, and his own gift, adorns the apartments of the Royal Society.

\title{
Obituary
}

\section{Prof. Harlan W. Fisk}

$\mathrm{T}^{\mathrm{H}}$ HE science of terrestrial magnetism has lost an outstanding investigator and the staff of the Carnegie Institution of Washington an esteemed member by the sudden death, on December 26, of Prof. Harlan Wilbur Fisk, chief of the Section of Land Magnetic Survey of the Institution's Depart. ment of Terrestrial Magnetism. During his long period of service with that organisation, extending over more than a quarter-century, he contributed much to the success of the world magnetic survey both by personal participation in the observational work and by planning and supervising the work at repeat-stations for obtaining data where most needed for investigations in his complex field.

Prof. Fisk was born at Geneva, Kansas, on September 25, 1869, but his youth was spent in Minnesota where he received his fundamental scientific training at Carleton College, Northfield. Here his enthusiasm for mathematics and 
astronomy was awakened by contact with such inspiring teachers as W. W. Payne and H. C. Wilson. In 1899 he was appointed professor of mathematics at Fargo College (North Dakota). It was here that the problem of terrestrial magnetism first engaged his attention and he devoted his summer vacations (1904-6) to magnetic observations for the United States Coast and Geodetic Survey in the north-central and western States. His interest in this field grew so rapidly that in October 1906 he adopted it as his life work when he became associated with the Department of Terrestrial Magnetism.

Here Prof. Fisk focused his activities on the land magnetic survey-one of the major undertakings of the Department. He made two detailed surveys of the Bermuda Islands, in 1907 and 1922, and in 1908 conducted magnetic expeditions in Central America, in the West Indies, and in the northern countries of South America. He was also greatly interested in the investigations of possible eclipse effects on the earth's magnetic field and participated in several eclipse expeditions of the Department-the last was on the occasion of the eclipse of August 21, 1932, when he was in charge of three observing parties in New England. He took a prominent place in the instruction of many of the Department's most active observers and in the laborious observations during many years in Washington, D.C., relating to the control of instrumental outfits and the determination of the provisional international magnetic standards.

Prof. Fisk's chief research contribution was the investigation of secular changes in the earth's magnetism and of the shifting of isoporic foci disclosed by magnetic data obtained at strategic repeat-stations by observers under his supervision. Mature deliberation led him to infer that secular changes in the earth's magnetism determined by observations on its surface might reflect changes within the earth's crust or interior. At the time of his death, he had in preparation an exhaustive paper on this subject.

Besides membership of a number of scientific societies, Prof. Fisk was an active worker in the American Geophysical Union, being secretary of its Section of Terrestrial Magnetism and Electricity in 1929-32. Because of an unusual breadth of culture extending far beyond the confines of his scientific activity, it was his pleasure and privilege to render important service to his community in its civic and religious life. His quiet disposition, generous nature, and helpful counsel, won him the esteem of his colleagues and friends. Those who shared his acquaintance and work, will mourn with his widow and four children his premature passing.

H. D. HaRradon.

\section{Mr. B. H. SoUlsby}

Mr. B. H. Soulsby, who died at Reading on January 14, aged sixty-eight, was for nearly thirty-eight years in the service of the Trustees of the British Museum, first at Bloomsbury and later at South Kensington. He was educated at Cheltenham College and at Corpus Christi College, Oxford, and also studied at Göttingen. He entered the service of the Trustees as a second-class assistant in the Department of Printed Books in 1892, and became successively superintendent of the Map Room, of the Copyright Office, and finally deputy superintendent of the Reading Room. During his time at Bloomsbury, he catalogued the library of the Grand Priory of the Order of the Hospital of St. John of Jerusalem in England, and translated some early geographical works. In 1902 he published a small pamphlet on the earliest two maps which bear the name America.

In $1909 \mathrm{Mr}$. Soulsby was transferred to the Natural History Museum as assistant in the Director's office, and in January 1921 he was appointed librarian in succession to the late $\mathrm{Mr}$. B. B. Woodward. His principal official duty was to continue Woodward's Catalogue of the Natural History Library, a monument of bibliographical care and research and a mine of information, the value of which was recognised far beyond the limits of the Library to which the work refers. Woodward had compiled six volumes and one supplementary volume, and at the time of Mr. Soulsby's retirement, the second supplementary volume was well on the way to completion.

At the time of his death, Mr. Soulsby was seeing through the press the final stages of a revised, second edition of the "Catalogue of the Works of Linnaus ... in the British Museum". The first edition, which was compiled by B. B. Woodward and W. R. Wilson, was a quarto publication of 27 pages, comprising some 580 entries. The second edition will contain about 300 pages of text, with nearly four thousand entries, accompanied by bibliographical notes, plates and an index.

It was upon this index that $\mathrm{Mr}$. Soulsby was engaged, with his accustomed industry and enthusiasm, at the time of his death. The forthcoming publication of this Linnæan Catalogue is a matter of great interest to librarians in Sweden, from several of whom Mr. Soulsby obtained considerable assistance in its preparation. The com. piler used to claim that the collection of Linnæana at South Kensington was second only in richness and importance to that at the Royal University Library of Uppsala, and if this is so, it is largely due to Mr. Soulsby's great generosity, inasmuch as ever since he undertook the work of producing a second edition of this catalogue, he was continually presenting rare and costly Linnaana to the library at South Kensington.

\section{Mr. J. L. S. HatToN}

John Leigh Smeathman Hatton, who died on January 13, aged sixty-seven years, was the first principal of East London College and, at the time of his death, Vice-Chancellor of the University of London. He was born at Street Aston on May 27, 1865, the son of the Rev. J. L. S. Hatton, 